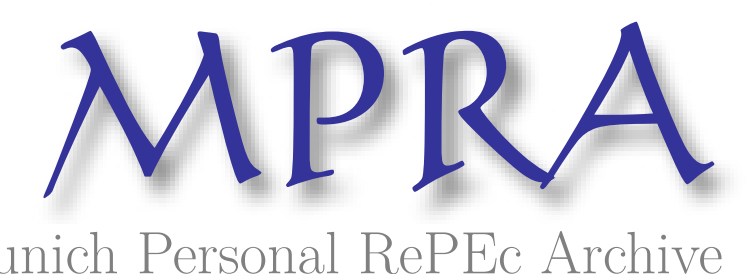

Munich Personal RePEc Archive

\title{
Financial collateral Arrangements under Directive 2002/47/ec of the European Parliament and of the Council of 6 June 2002
}

Ivan, Mangatchev

9 May 2008

Online at https://mpra.ub.uni-muenchen.de/12253/

MPRA Paper No. 12253, posted 20 Dec 2008 10:37 UTC 


\title{
FINANCIAL COLLATERAL ARRANGEMENTS UNDER DIRECTIVE 2002/47/EC OF THE EUROPEAN PARLIAMENT AND OF THE COUNCIL OF 6 JUNE 2002
}

\author{
Ivan P. Mangatchev, LLM \\ Assistant Professor \\ Department of Law \\ New Bulgarian University \\ mangatchev@gmail.com
}

\begin{abstract}
The aim in this article is to compare effect of financial collateral arrangements under Directive 2002/47 EC. The starting point is the definitions of these contracts provided by the Financial Collateral Directive. The financial collateral arrangements have their historical roots in Roman law. Their effect introduces new legal framework in EU secured transaction legislation. For appropriate understanding of their legal nature a comparative examination between two secured transactions is needed. The conclusions of the article summarize the ideas which may useful in future amendments of the Directive 2002/47 EC.
\end{abstract}

\section{Definitions of financial collateral arrangements}

Directive 2002/47/EC of the European Parliament and of the Council of 6 June 2002 (so called 'Financial Collateral Directive' has been transposed member states legislation'. FCD regulates two different types of collateral contracts - title transfer financial collateral arrangement and security financial collateral arrangement ${ }^{2}$.

Title transfer financial collateral arrangement is defined as an arrangement, including repurchase agreements, under which a collateral provider transfers full ownership of financial collateral to a collateral taker for the purpose of securing or otherwise covering the performance of relevant financial obligations ${ }^{3}$.

Security financial collateral arrangement is a contract, under which a collateral provider provides financial collateral by way of security in favour of, or to, a collateral taker, and where the full ownership of the financial collateral remains with the collateral provider when the security right is established ${ }^{4}$.

\footnotetext{
1 European legislation financial markets, http://www.ecb.int/pub/pdf/other/europeanlegislationfinancialmarkets200706en.pdf, 53-61

${ }^{2}$ Art. 2, 1 (a) FCD

${ }^{3}$ Art. 2, 1 (b) FCD

${ }^{4}$ Art. 2, 1 (c) FCD
} 
According to the definitions above, there is a basis to conclude that these two secured transactions have common contracting parties - collateral provider (secured debtor) and collateral taker (secured creditor). The financial collateral arrangements are real contracts, because the financial collateral should be delivered, transferred, held, registered or otherwise designated so as to be in the possession or under the control of the collateral taker ${ }^{5}$. The only objects of these contracts could be only cash $^{6}$ or financial instruments ${ }^{7}$.

But is this information enough in order to understand fully the legal nature and effect of these two secured contracts? Is the ownership the only difference between them? If we would like to find the right answers to the questions above, we should examine their effect and afterwards compare those to collateral agreements. Conclusions may be helpful for eventual future amendments in the FCD.

\section{Historic roots in the Roman law}

Title transfer financial collateral arrangement and security financial collateral arrangement are new legal notions, but they have their historical roots in the Roman law. The origin of title transfer financial collateral arrangement may be found in fiducia cum creditore contracta $^{8}$. In fiducia cum creditore contracta the fiduciant (secured debtor) transferred the ownership to the fiduciary (secured creditor) on condition that he would transfer it back when the debt was paid ${ }^{9}$. This transfer was made by mancipatio or in jure cessio ${ }^{10}$, which was done in abstract and solemn form. The new owner (mancipio accipiens) took in his hand the chattel from the previous owner (mancipio dans). At this moment the man with scales (libripens) rang them by small piece of bronze (aes et libra) ${ }^{11}$. The return of the chattel was possible with the special actio fiduciae. The actio fiduciae did not provide any protection for the initial (and subsequent) owner from the risk of loosing the chattel ${ }^{12}$ (for example in case of bankruptcy of the creditor ${ }^{13}$ ). It was not surprising that the conviction in an actio fiducia for recovery of such a pledge was infaming ${ }^{14}$.

\footnotetext{
${ }^{5}$ Par. 9, Preamble FCD

${ }^{6}$ Art. 2, 1, (d) FCD - (d) "cash" means money credited to an account in any currency, or similar claims for the repayment of money, such as money market deposits

${ }^{7}$ Art. 2, 1, (e) FCD - (e) "financial instruments" means shares in companies and other securities equivalent to shares in companies and bonds and other forms of debt instruments if these are negotiable on the capital market, and any other securities which are normally dealt in and which give the right to acquire any such shares, bonds or other securities by subscription, purchase or exchange or which give rise to a cash settlement (excluding instruments of payment), including units in collective investment undertakings, money market instruments and claims relating to or rights in or in respect of any of the foregoing.

${ }^{8}$ Stec, P., Fiducia in an Emerging Economy, W: E. Cooke (ed.): Modern Studies in Property Law, vol. 2, Hart Publishing, Oxford (2003) 43

${ }^{9}$ Stec, P., Ibid. 44

${ }^{10}$ Cracknell, D.G., Wilson, C.H., Roman Law: Origins and influence, HLT Publications, London (1990) 170

${ }^{11}$ Дюнан, Ж., Пишона, П., Римско право, Речник на основните термини, Ciela (2007)

${ }^{12}$ Венедиков, П., Записки по римско право, ИК “Проф. Петко Венедиков” (1999) 89

${ }^{13}$ Покровский И.А., История Римского Права. Издание 3-е, исправленное и дополненное //
} 
As for the effects to the security financial collateral arrangements there is a possibility for the collateral taker to appropriate financial instruments which are the subject to the contract $^{15}$. The agreement with possibility for the creditor to acquire the ownership of the collateral was known in the Roman law as lex comissoria. The creditor had the right to become an owner of the security if the debtor failed to pay the debt ${ }^{16}$. This agreement differs from fiducia cum creditore contracta. The moment of appropriation of the ownership over the collateral was disparate. In fiducia cum creditore contracta the ownership was transferred by the fact of conclusion of the contract. In lex comissoria the result would be the same only in case of negligence.

\section{Analysis of title transfer collateral arrangements}

Is the title transfer financial collateral arrangement the same as security fiduciary contract (fiducia cum creditore contracta)? The answer to this question may be found in comparing in effects these two contracts.

\subsection{Effect}

The legal theory shares the opinion of prohibition of fiducia cum creditore contracta. According to the legal theory security fiduciary contract transfers property rights which the new owner binds to return transfer back to the previous one ${ }^{17}$. The fiduciant (the initial and subsequent owner) and the fiduciary (temporary) are the parties to the contract ${ }^{18}$.

The fiduciant is the real owner of the transferred property. The change in the ownership is made to secure creditor's obligation that should use the effect only in case of debtor's default ${ }^{19}$. The fiduciary contract has been defined as a contract, which contains secret element (back transfer stipulation), which requires silence ${ }^{20}$. The aim of the fiduciary contracts is to hide the fact of transferring the ownership back to the fiduciant (the fiduciant is peremptory owner ${ }^{21}$ ).

\footnotetext{
Allpravo.Ru - 2004, http :// allpravo . ru / library / doc 2527 p 0/ instrum 3503/ print 3611 . html (1917)

${ }^{14}$ Crook, J., A., Law and life of Rome, Thames and Hudson (1967) 246

15 Art. 4, 1, (a) FCD

${ }^{16}$ Дюнан, Ж., Пишона, П., ор. cit.

${ }^{17}$ Павлова, М., Гражданско право - обща част, Второ преработено и допълнено издание, Софи-Р (2002) 471

${ }^{18}$ Таков, К., Доброволно представителство, Сиби (2006) 109

${ }^{19}$ Кацаров, К., Систематичен курс по българско търговско право, Четвърто фототипно издание, С. (1990) 878

${ }^{20}$ Таков, К., ор. cit., Сиби, С. (2006) 109

${ }^{21}$ Таков, K., Персонална симулация - видове, хипотези, сравнения с други правни конструкции, Юридически свят, 2 (2005) 81
} 
The similarity between fiduciary contract and title transfer financial collateral arrangement is in their function to give security by change the ownership ${ }^{22}$. They both include two sales relationships: initial - to provide security and subsequent - to transfers back the ownership. The subsequent one depends on the existence of an enforcement event ${ }^{23}$.

The differences between fiduciary contract and title transfer financial collateral arrangement may be found in many directions. First of all, according to legal theory the fiduciary contract is a consensual contract as the sales contract. The title transfer financial collateral arrangement, on the contrary is the real one. Secondly the title transfer financial collateral arrangement may not contain any secret element as a registration of the financial collateral arrangement is provided for.

\subsection{Rights and obligations}

As mentioned above, the title transfer financial collateral arrangement presupposes the existence of financial obligation. The rights and obligations of the both parties depend on the performance of the legal relationship, which is subject to different contracts. In case of default, the collateral taker has the right to use either the close-out netting or netting by novation option (the later to be agreed beforehand).

\subsubsection{Back transfer obligation}

When the collateral provider transfers the ownership over the collateral, collateral taker has an obligation (in case of performance) to transfer back the collateral to the initial owner (the collateral provider). The collateral provider has no rei vindicatio right in case of collateral taker's disposal.

\subsubsection{Close-out netting}

The netting is a special form of set-off, which is available in settlement systems. The close-out netting (which is known as default netting ${ }^{24}$, replacement contract risk, close-out netting, open contract netting or replacement contract netting ${ }^{25}$ ) is netting which takes place only in case of default. The close out netting is effective even in bankruptcy proceedings. The

\footnotetext{
${ }^{22}$ Марков, М., Някои въпроси във връзка с прехвърлителните договори, Юбилеен сборник в чест на професор Живко Сталев, Сиби (2005) 227

${ }^{23}$ Art. 2, 1, (1) FCD - "enforcement event" means an event of default or any similar event as agreed between the parties on the occurrence of which, under the terms of a financial collateral arrangement or by operation of law, the collateral taker is entitled to realise or appropriate financial collateral or a close-out netting provision comes into effect.

${ }^{24}$ Cf. Wood, Ph., Title Finance, Derivatives, Securitisations, set-off and Netting, 1st ed, London, Sweet \& Maxwell (1995) 152-153

${ }^{25}$ Wood, Ph., Ibid., p. 153
} 
provision of close-out netting is usually a provision in a financial collateral arrangement. It takes place only in case of default and is effective even in bankruptcy proceedings ${ }^{26}$.

It should be noted that the close-out netting differs from settlement netting (which is also known as delivery netting, payments netting or position netting ${ }^{27}$ ). The settlement setting is the process in which the obligations are netted and paid. This payment has the aim to help the fulfillment of obligations ${ }^{28}$, not to secure them.

The other effect of close-out netting is the obligations to set-off. The mutual obligations are transformed into the payment obligations and set-off to the lesser obligation ${ }^{29}$. The netting is closer in effect to the set-off, but they are not the same ${ }^{30}$. The content of the term "netting" is broader than set-off"

\section{Analysis the security financial collateral arrangement with right of use}

Obligations for the collateral taker only arise under security collateral arrangement with right of use clause. The collateral taker has the same obligation as the pledgee - to return the collateral to the collateral provider. In case of collateral arrangement with right of use clause the collateral taker has an additional obligation which is connected with related to the execution of the right of use. If the collateral taker exercises the right of use, he obliged himself to transfer equivalent collateral to replace the original one. This obligation should be fulfilled not later than the due date for the performance of the relevant financial obligations covered by the security financial collateral arrangement ${ }^{32}$.

\subsection{Right of use}

The right of use is the right of the collateral taker to use and dispose of the financial collateral provided under a security financial collateral arrangement as the owner of it in accordance with the terms of the security financial collateral arrangement ${ }^{33}$.

This right arises from the moment when the collateral has been provided and exists through whole period during which the collateral is under the control of the collateral taker or

\footnotetext{
${ }^{26}$ Art. 7 FCD

${ }^{27}$ Report on netting schemes (Angell Report) (1989) http://www.bis.org/publ/cpss02.pdf 11

${ }^{28}$ Cf. Wood, Ph., Principles of international insolvency, Sweet \& Maxwell, London (1995) 104

29 Goris, P., The legal aspect of swaps: An Analysis Based on Economic Substance, Graham \& Trotman/Martinus

Nijhoff, London/Dordrecht/Boston (1994) 213

${ }^{30}$ Goode, R., Legal problems of credit and security, Third edition, Sweet \& Maxwell, London (2003) 241

${ }^{31}$ Wood, Ph., Title Finance, Derivatives, Securitisations, set-off and Netting, 1st ed, London, Sweet \& Maxwell (1995) 152 
of a person acting on the collateral taker's behalf. This right extinguishes when the relevant financial obligation stops to exists or in the event of realization of the collateral.

The right of use differs from the right of ownership. Up to the moment when the right of use is exercised the owner has been a collateral provider ${ }^{34}$. The transfer of the ownership is a compulsory prerequisite in the title transfer financial collateral arrangement, but the right of use is only a possibility in the security financial collateral arrangement. In addition, the examination of right of use gives rise to the following rights and obligations:

1. The collateral taker should transfer equivalent collateral to replace the original financial collateral at the latest on the due date for the performance of the relevant financial obligations covered by the security financial collateral arrangement; or

2. Alternatively, the collateral taker may, on the due date for the performance of the relevant financial obligations, either transfer equivalent collateral, or, if and to the extent that the terms of a security financial collateral arrangement so provide, set off the value of the equivalent collateral against or apply it in discharge of the relevant financial obligations ${ }^{35}$.

The security financial collateral arrangement differs also from irregular pledge. A pledge qualifies as 'irregular' provided that a) the pledge concerns money, chattels or securities, and $b$ ) the parties consider that such assets belong to a genus ${ }^{36}$. The creation of an irregular pledge essentially entails a transfer of ownership for security purposes ${ }^{37}$. Despite seemingly similarity between irregular pledge and security financial collateral arrangement, they are not the same. The ownership in irregular pledge transfers at the time of conclusion of the contract and not when the right of use is exercised.

\subsection{The obligation of equivalent collateral transfer}

The obligation to transfers equivalent collateral transfer arises when right of use is exercised. As this obligation is for reciprocal collateral transfer, it is new for many legal systems. The attention should be paid to the definition "other assets". If other assets are acceptable for collateral, it would break the limitation of the FCD objects ${ }^{38}$. The abolishment of the words "other assets" in FCD/ LFCA should be recommended.

\footnotetext{
${ }^{34}$ Keijser, T., Report on a Right of Use for Collateral Takers and Custodians, Law and Economics 0308001, EconWPA, revised 14 Nov 200 \& ed., http://129.3.20.41/eps/le/papers/0308/0308001.pdf (2003) 18-19

${ }^{35}$ Art. 5, 2 FCD

${ }^{36}$ Keijser, T., op. cit., 43

${ }^{37}$ Ibid.

${ }^{38}$ Art. 2, 1, (d) and (e) FCD
} 


\subsection{Collateral appropriation}

The appropriation of ownership over the collateral is a right of the collateral taker in case of default ${ }^{39}$. This right may occur under the security financial collateral agreements. This is an extinguishing manner for peremptory execution of the parties' obligations.

Other manner of appropriation of ownership over the collateral is the execution of the right of use ${ }^{40}$. In this case the collateral taker is considered as an owner. It differs from the previous appropriation manner because it does not require event of default. The formation of this appropriation is dependant from two cumulative prerequisites:

1. this right should be provided by the security financial collateral arrangement ${ }^{41}$; and

2. collateral taker should exercise the right of use ${ }^{42}$.

The above mentioned manners of appropriation should be differentiated from those in the title transfer financial collateral arrangement. The difference is in the time of their origin. In the security financial collateral agreement the appropriation is only possibility when the right of use is exercised of or there is a default. Up to this moment the owner of the collateral is the collateral provider ${ }^{43}$.

The methods of appropriation ways are specific for collateral transfer back to the collateral provider in the title transfer financial collateral arrangement. In case of performance the collateral taker should transfer back the initial collateral to the collateral provider. In case of security collateral arrangement with the right of use the collateral taker should transfer back not the same, but equivalent collateral ${ }^{44}$.

\section{Conclusions}

It may be concluded that some changes in FCD are needed. An amendment of the title transfer financial collateral arrangement should be recommended in order to clarify the transfer back obligation that concerns the initial, but not equivalent collateral. If we accept the possibility for collateral taker to return back equivalent collateral, but not the initial one that would erase the difference between title transfer financial collateral arrangement and the security collateral arrangement with right of use clause. If the collateral taker disposes to the collateral, he/she should bear contract responsibility to the collateral provider. The rights acquired by the third parties should be unencumbered. The close-out netting applicability in the title transfer financial collateral arrangement is without justification, because the collateral taker is the owner of the collateral and he/she has the right to disposes of it as he/she deems necessary to do.

\footnotetext{
${ }^{39}$ Art. 4, 1, (a) FCD

${ }^{40}$ Art. 2, 1, (m) FCD

${ }^{41}$ Art. 5, 1 FCD

${ }^{42}$ Art. 5, 2 FCD

${ }^{43}$ Art. 2, 1, (c) FCD

${ }^{44}$ Keijser, T., op. cit., 55
} 
The security collateral arrangement with right of use clause does not provide any defense for the good faith collateral provider. The equivalent collateral is in the possession or under the control of the collateral taker or of a person acting on the collateral taker's behalf. It would be impossible for the collateral provider to use close-out netting provision. If an enforcement event occurs while any obligation of the collateral taker to transfer equivalent collateral under a title transfer financial collateral arrangement remains outstanding ${ }^{45}$, the collateral provider would not have an object over which to exercise his/her right of close-out netting.

\footnotetext{
${ }^{45}$ As provide Art. 6, 2 FCD
} 